\title{
Investment Attractiveness of Regions: Gender Factors
}

Nugumanova L.F.

Novenkova A.Z.

Abdulganiev F.S

Kazan Federal University, Kazan, 420008, Russia

\section{Doi:10.5901/mjss.2014.v5n18p79}

\section{Abstract}

This article deals with different approaches to the interpretation of the term investment potential, analyzes the factors of investment attractiveness of the enterprise. Invited to identify the degree of influence of gender on the investment attractiveness of the enterprise. This analysis allows is to estimate the influence of the gender factors on the state of the brandcapital of the territory. The gender component of the demographic potential way analyzed with regard to the age structure, educational level, span of life and differences in payment for labor. The role of women in the progressive development of the economic and social values of the territorial entities was closely analyzed. It has been proved, that taking into consideration the importance of the gender factor is crucial for the rise of the investment attractiveness of the territorial entity.

Keywords: Gender factors, demographic potential of the territory, territories, labor market, economic ally active population, investment attractiveness.

\section{Introduction}

The inalienable component of the brand-capital of the territorial entities and the national economy as a whole is the demographic potential, which is formed under the influence of several objective and subjective factors. One of the major characteristics of the demographic potential is the gender component. The fluctuations of the latter could influence the investment attractiveness of the territory as well as the trends and pace of the economic activity indicators of the population.

Present analysis is aimed at the determination of the provisions fulfillment of the UN Convention on the Elimination of all Forms of Discrimination against Women (CEDAW) on the territory of the Russian Federation, which will help to find out the relevance of the gender factor for the image of the territorial entities and the national economy in general.

\section{Methodology}

According to the data of the Federal Service the State Statistics the total amount of the population in the Russian Federation was 143 million people, which is 5 million less than in 1991 and 1996. The majority of the population are women. Besides, there were 9,3 million women more than men in 1991 and 1996, whereas in 2012 the discrepancy was already 10,8 million. So, we can observe a clear tendency, namely, the female population is increasing, when male population is decreasing. (Table 1) [1]. 
Table 1: The number of male and female population of the Russian Federation in 1991-2011

\begin{tabular}{|c|c|c|c|c|c|}
\hline \multirow{2}{*}{ Year } & \multirow{2}{*}{ Total population, mln. } & \multicolumn{2}{|c|}{ Among them } & \multicolumn{2}{c|}{ Percentage of the total population } \\
\cline { 3 - 5 } & & males & females & males & females \\
\hline 1991 & 148,3 & 69,5 & 78,8 & 47 & 53 \\
\hline 1996 & 148,3 & 69,5 & 78,8 & 47 & 53 \\
\hline 2001 & 146,3 & 68,3 & 78,0 & 47 & 53 \\
\hline 2002 & 145,2 & 67,6 & 77,6 & 47 & 53 \\
\hline 2003 & 145,0 & 67,5 & 77,5 & 47 & 53 \\
\hline 2004 & 144,3 & 67,0 & 77,3 & 46 & 54 \\
\hline 2005 & 143,8 & 66,7 & 77,1 & 46 & 54 \\
\hline 2006 & 143,2 & 66,3 & 76,9 & 46 & 54 \\
\hline 2007 & 142,8 & 66,0 & 76,8 & 46 & 54 \\
\hline 2008 & 142,8 & 66,0 & 76,8 & 46 & 54 \\
\hline 2009 & 142,7 & 65,9 & 76,8 & 46 & 54 \\
\hline 2010 & 142,9 & 66,1 & 76,8 & 46 & 54 \\
\hline 2011 & 142,9 & 66,1 & 76,8 & 46 & \\
\hline
\end{tabular}

According to the data of the Federal service of the state statistics (Table 2), the gender gap of the expected lifespan between men and women within the period from 1992 to 2013 started to decrease. Thus, in 1991 the gap was 12 years, whereas in the year of 2013 this gap was already 11 years. The average lifespan (in 2012) for men was 64 years and for women 75 years, respectively.

Table 2: The lifespan for men and women in the Russian Federation, 1992-2012

\begin{tabular}{|c|c|c|}
\hline \multirow{2}{*}{ Year } & \multicolumn{2}{|c|}{ Total population } \\
\cline { 2 - 3 } & males & females \\
\hline 1992 & 62 & 74 \\
\hline 1993 & 59 & 72 \\
\hline 1994 & 58 & 71 \\
\hline 1995 & 58,12 & 71,59 \\
\hline 2000 & 59,03 & 72,26 \\
\hline 2001 & 58,92 & 72,17 \\
\hline 2002 & 58,68 & 71,9 \\
\hline 2003 & 58,53 & 71,85 \\
\hline 2004 & 58,91 & 72,36 \\
\hline 2005 & 58,92 & 72,47 \\
\hline 2006 & 60,43 & 73,34 \\
\hline 2007 & 61,46 & 74,02 \\
\hline 2008 & 61,92 & 74,28 \\
\hline 2009 & 62,87 & 74,79 \\
\hline 2010 & 63,09 & 74,88 \\
\hline 2011 & 64,04 & 75,61 \\
\hline 2012 & 64,56 & 75,86 \\
\hline
\end{tabular}

In Russia the gender gap of the expected lifespan at birth still remains one of the biggest in the world. The main reason for the life span gender gap in Russia is the fact, that the male death rate remains higher than that of women for people of all ages.

According to the data of the Federal Service of the State Statistics every second marriage breaks up. There were 644101 divorces (about 53\%) for 1213598 marriages, and in the 90s 559918 divorces (about 42\%) for 1319928 marriages. Dynamically, the statistics of divorces became the indicator of the family values collapse. Besides, this process started not in the 90s but at the very beginning of the stagnation epoch, in the 70s, to be more exact. The divorces in last decades were characterized by alcoholism and drug dependency (rise from 33\% to $51 \%$ from 1990 to 2007), the absence of own accommodation (rise from $21 \%$ to $41 \%$ ) and inability to provide for the family properly (from 
$8 \%$ to $29 \%$ ). These are the causes of marriage collapse (The VTSIOM${ }^{1}$ Questionnaire of February 2007) [3].

According to the data of the Federal Service of the State Statistics the level of the male education in the Russian Federation fell far behind the female one. The higher is the educational level, the bigger is the number of women among the total amount of students. [3].

Table 3: The level male and female education in the Russian Federation

\begin{tabular}{|l|c|c|c|c|c|c|c|c|}
\hline & \multicolumn{4}{|c|}{2002} & \multicolumn{4}{|c|}{2010} \\
\hline & \multicolumn{2}{|c|}{ Thousands of people } & \multicolumn{2}{c|}{$\begin{array}{c}\text { Distribution according } \\
\text { to the sex }\end{array}$} & \multicolumn{2}{|c|}{$\begin{array}{c}\text { Thousands of } \\
\text { people }\end{array}$} & \multicolumn{2}{|c|}{$\begin{array}{c}\text { Distribution } \\
\text { according to the sex }\end{array}$} \\
\hline & Women & Men & Women & Men & Women & Men & Women & Men \\
\hline $\begin{array}{l}\text { Total population at the age of 15 and older } \\
\text { (indicated the level of education) }\end{array}$ & 65183 & 54753 & 54 & 46 & 64335 & 53305 & 55 & 45 \\
\hline Besides they also have & & & & & & & & \\
\hline Professional education & & & & & & & & \\
\hline $\begin{array}{l}\text { Training higher education (including } \\
\text { postgraduate training) }\end{array}$ & 10766 & 8613 & 56 & 44 & 15975 & 11566 & 58 & 42 \\
\hline Incomplete higher education & 2018 & 1722 & 54 & 46 & 2928 & 2460 & 54 & 46 \\
\hline Secondary & 19052 & 13877 & 58 & 42 & 20672 & 16063 & 56 & 44 \\
\hline Primary & 6661 & 8706 & 43 & 57 & 2806 & 3728 & 43 & 57 \\
\hline General education & & & & & & & & \\
\hline Secondary (full) & 10938 & 10338 & 51 & 49 & 10735 & 10734 & 50 & 50 \\
\hline Main & 8882 & 7813 & 53 & 47 & 6622 & 6310 & 51 & 49 \\
\hline Primary & 5948 & 3402 & 64 & 36 & 4128 & 2200 & 65 & 35 \\
\hline No primary education & 918 & 282 & 76 & 24 & 469 & 244 & 66 & 34 \\
\hline
\end{tabular}

Higher professional education and training were and still are highly feminized. The share of male students among the HEES (Higher Educational Establishments) students is growing very slowly. About 60 years will be required to achieve the stated "equal representation of male and female students among those in the higher professional educational establishments" under the current pace of the smoothing of students' membership misbalance at this level of education. One more gender problem of the educational system was and still is the feminization of the branch above and the tutors' staff. The share of women among all those engaged in education (as a branch of economy) was extremely big and has even grown so far.

Maximum share of women among the employed here fell on the year of 1995 when it was $83 \%$. At present every eight of the ten working in this sphere are women [2].

Most part of the economically active population both man and women, is a hired labour force (in 1999 the share of men was $94,5 \%$, women - 92,1\%; in 2011 that of women was 93,7 and men-92,1\%). The main part of their welfare is formed at the cost of their employment and salary. That is why the basis of economic gender equality or inequality is the status of men and women on the labour force market. The state of affairs on the market itself is determined first of all in accordance with two main criteria: the indexes of employment and unemployment.

During the years of reformation (in state education) important changes in the sphere of employment and the situation on the labor force market have changed dramatically. According to the data provided by the RF Ministry of Public Health and social security, the changes above first of all led to the exacerbation of gender asymmetry: i.e. economic activity of the able-bodied women (capable for work) went down sharply (from 82\% in 1992 (up) to $74 \%$ in 202). However, according to the Federal service of the state statistics, the women's activities started growing up then and achieved $76,1 \%$ in 2011. For the last twenty years the number of women engaged in economy has remained unchanged: in the 1990s this figure was 33 million women or 49\% of the total number of the employed and in 2011 the figure was 34 million (49\%). The level of economic activity of women for the last twenty years has been backward that of men (49\% against 51\%) (table 4).

\footnotetext{
${ }^{1}$ All-Russian Center for the Study of Public Opinion
} 
Table 4: The level of economic activity of men and women, 1992-2011

\begin{tabular}{|c|c|c|c|c|}
\hline \multicolumn{5}{|c|}{ (Full) Employment in economy } \\
\hline year & thousand of people & \multicolumn{2}{c|}{ distribution according to sex, \% } \\
\hline & women & men & women & men \\
\hline 1992 & 33923 & 37145 & 49 & 51 \\
\hline 1995 & 30429 & 33720 & 47 & 53 \\
\hline 1996 & 39841 & 33087 & 47 & 53 \\
\hline 1998 & 27850 & 30587 & 48 & 52 \\
\hline 1999 & 29223 & 32039 & 48 & 52 \\
\hline 2001 & 31229 & 33435 & 48 & 51 \\
\hline 2003 & 32473 & 34023 & 49 & 51 \\
\hline 2005 & 33893 & 34710 & 49 & 50,6 \\
\hline 2006 & 34161 & 34996 & 49,4 & 50,4 \\
\hline 2007 & 35110 & 35704 & 49,6 & 50,8 \\
\hline 2008 & 34734 & 35869 & 49,2 & 50,9 \\
\hline 2009 & 34086 & 35275 & 49,1 & 51 \\
\hline 2010 & 34367 & 35566 & 49 & 51 \\
\hline 2011 & 34824 & 36032 & 49 & \\
\hline
\end{tabular}

Women's labor is used mainly in service industries trade, education, public health care, that is, in the least paid branches of economy of socio-cultural orientation and this tendency has not changed since 1992, whereas men have been strengthening their positions in the most profitable branches.

The level of unemployment, calculated in accordance with the MOT-technique, for the period of 1992-1998 grew from $5,1 \%$ to $13,5 \%$ (whereas the officially registered unemployment varied from $0,8 \%$ to $2,7 \%$ during this period). In absolute magnitudes the dynamics of unemployment looks as follows: in 1992 the RF Goskomstat investigation on the problems of employment recorded 3,9 million of unemployed and in 1998 the figure hit the mark of 8,9 million (44,8\% of whom were women) and by 2011 46\% of the total number of unemployed were women.

At first sight the dynamics of unemployment is more propitious in women than in men but one should not forget about so-called latent unemployment. Russia's realities are the following: the scale and level of the officially-registered unemployment could significantly increase at any moment at the expense of latent unemployment, which was estimated by various experts as equal to $7-15 \%$ of the total number of unemployed up to the middle of 1998 . Besides, speaking of unemployment it is also appropriate to say about the differentiation (according to sex) of the magnitudes of some separate indexes charactering the quality of men's and women's unemployment, for example, the differentiation of the average duration of job searching (women's unemployment is much longer (in 1998 it was 8,9 months for men and 9,3 for women; and in 2011 - 7,9 months for men and 8,1 months for women, respectively); differences in the root causes of unemployment, for example, women become redundant much more often than men: in 1999 it was $75,6 \%$ for women against 30\% for men, but in 2011 the percentage was the following: 21\% for in women and 20,4\% - for men). Moreover, women less often become unemployed due to voluntary resignation from the enterprise: in 1999 such type of unemployed women counted $17,2 \%$ of the total number of unemployed women, whereas that of unemployed men counted 24,5\%; the number of the resigned women grew up to 20,3\% and men - 25,6\%, respectively, in 2011.

According to the expert's opinion, the share of women in the total volume of unofficial employment is evaluated within the limits of 35-39\%, which means 5-6 million people.

One of the key "female" problems of the Russian sphere of employment is a significant gender gap in payment for labor. In accordance with the state statistics federal service data, such a gap diminished only slightly, namely, by $1 \%$ and became $64 \%$ within the period from the late 90s to 2011 (table 5). 
Table 5: The average monthly nominal charged salary/ wages for women and men in different branches of economy, 1999-2011

\begin{tabular}{|c|c|c|c|}
\hline \multicolumn{4}{|c|}{ The average monthly nominal charged salary/ wages for women and men in different branches of economy } \\
\hline Year & Average monthly salary/ wages, in rubles & The ratio of women's to men's salaries/ wages, \% \\
\hline & Women & Men & 65 \\
\hline 1999 & 1236 & 1906 & 63 \\
\hline 2001 & 2356 & 4203 & 64 \\
\hline 2003 & 4640 & 7194 & 61 \\
\hline 2005 & 7153 & 11778 & 63 \\
\hline 2007 & 11326 & 17949 & 65 \\
\hline 2009 & 15639 & 23946 & 64 \\
\hline 2011 & 19219 & 30005 & \\
\hline
\end{tabular}

According to the UN experts, the gender gap in payment for labor in Russia in formed under the influence of the whole system of factors, most of which result from the spread of direct and indirect discriminating practices against women (while hiring and firing; job promoting; even paying for equal labor differently) and traditional division of labor between men and women. Among those factors experts first of all point out the coexistence of, on the one hand, significant differentiation in payment for labor in accordance with the types of economic activity and on the other hand, - segregation according to them (i.e. non-uniform distribution of men and women according to the types of economic activity). As a result, women are much more often involved in low-paid types of human activities.

One more factor of gender differences in payment for labor is professional and vertical segregation (which is very often the consequence of discrimination of women in profession(al) promotion and career making. The segregation above leads to the situation when well-paid jobs, positions and places of employment become inaccessible to women. That is why there are gender differences concerning the level of labor payments, salaries and wages in all branches of economy: namely, both feminized and those where the majority of employed are men (maximum differences $32,8 \%$ fall on production/ processing industries, minimum - 10,7\%, - on education). It should be especially emphasized that vertical segregation is shaped in the conditions of higher level of professional education and training in women compared with men. It speaks about the fact that, within the framework of Russian society and Russian economy, education does not fulfill one of its main functions for women, namely, the function of "social lift". The alterations of gender gaps in payment for labor, which are connected with sectoral, professional and vertical segregation could be furthered via the state measures dealing with the labor payment rise. It is habitual to study paid labor in the sphere of social economy separately from women's non-paid work in housekeeping. The analysis of inter-dependencies of market and home spheres of activities allows us to reveal the mechanism of "vicious circle" reproducing gender disparity in society. Its very essence is in the following: women's household chores restrict her potentialities on the labor market and make conditional their lower salary/ wages, which in its makes turn the woman dependent on her husband's salary/ wage and consolidates the division of labor within the family. As better-paid places of employment are normally at men's disposal, that is why even having job, women are still materially dependent upon their husbands.

In spite of the high level of women's labor activity arisen in the second half of the XX/ twentieth century, the unwritten "social treaty", which consolidated the distribution of the roles in the family and on the labor market, is still in force. This tendency could be observed in the 90s (of the last century) as well as it can be observed now. Moreover, it leads to the situation when (especially taking into account a high level of Russian women(s) employment), the time of men is mainly divided up between work and leisure, whereas the time of women - among work, leisure and housekeeping (table 6).

Table 6: The distribution of household chores between women and men in 2011

\begin{tabular}{|l|l|l|}
\hline & Women & Men \\
\hline Everything or practically everything is done by the wife & & \\
\hline Each has their own chores, but most is done by the wife & & \\
\hline Most work about the house the wife and the husband do together or in turn & & \\
\hline Each has their own chores, but most is done by the husband & & \\
\hline Find difficulty in replying & & \\
\hline Other alternatives & & \\
\hline
\end{tabular}


The investigations carried out by the All-Russia center of Public opinion Studies and Polls (2013) lead to the conclusion that most Russian families still stick to "patriarchal" family model.

In the business sphere such a "gender rule" has appeared in such a way: occurred: the bigger business is the fewer women are engaged in it. Their representation in the entrepreneurial and banking finance elite is insignificantly low. Today more and more women start doing business, but their number among the top-managers of powerful multinational companies is about $10 \%$ only. According to the data presented by the information agency "Finmarket", the share of women managers counts only $15,62 \%$ of the total number of all appointments; and 7,2\% - among directors - general. Russian companies are even less inclined to attract women to manage if compared with transnational corporations $(14,7 \%$ and $18,5 \%$, respectively).

The share of women increased within the period of 2000-2007 and became stabilized in 2008-2009. Such growth can be explained in terms of growing demand for top managers during the economic boom in Russia, which, in its turn, was caused by the shortage of highly-qualified male managers. Moreover, the 2008-2009 crisis reduced the demand for all top-managers including women managers. In accordance with the data given by the information agency "Finmarket", among the RF economic sectors, which have the highest percentage of female managers, there are such sectors as recruiting, advertising, insurance, bookkeeping, consulting and law. Agriculture, hydrocarbons mining, coal mining, machine building, power engineering, metallurgy show the lowest percentage of women-managers. Besides, female managers are in the average and as a rule younger, than male-managers partly because of their earlier retirement and getting pensions. According to the statistical data presented by the European association of women- specialists, 200 biggest Western European companies have only 5\%of women - top-managers and $8 \%$ of women-board-members. The biggest number of female-members in the boards of directors is in Norwegian (18\%), Swedish (17\%), British (16\%) and Finish companies (11\%); as for Italian and Spanish companies (the percentage of women there is only $2 \%$ and $3 \%$, respectively/ Thus, the conclusion can be drawn that for the last 20 years (1992-2013) there were no crucial changes in the position of women in socio-economic sphere.

\section{Conclusions}

One of the factors of the new quality of economic growth determining the possibility to convert the innovation-investment economic potential into the source of more extensive and intensive type of reproduction, is the degree of women's involvement in social production. The growth of women's employment, in its turn, depends upon the growing level of education and qualification of women; the development of material and spiritual requirements which can be satisfied only while being employed; the creation of new spheres of activities, for which the woman is an effective (and-efficient) worker as well as upon the mechanism of the labor market state regulation, taking into account the psycho-physiological and socio-demographic characteristics of the female labor force.

Discrepancy and ambiguity of the tendencies and results of the Russian transformative economy development and its constituent element, namely, the labor market, result from the consequences of the internal dialectic contradiction in the mechanism of state regulation, which has become even stronger under the conditions of necessity to coordinate the efforts of numerous new agents appeared as a result of market reforms and economic growth. That has required the creation of new institutions including those aimed at the demolishing of gender stereotypes and orthodox division of labor between men and women; support of women's qualification level in the official sector of employment via the development of qualification structures and creation of adequate socio-demographic policy as well as the formation of the genderneutral social structure symmetrically open to individual self-actualization of any person, etc. Taking into account the gender factor is the necessary condition for the advancement of the investment attractiveness of branch/ sectoral territorial units (regions) characterized by the availability of the localized labor market [15].

Mechanical introduction of the developed states experience into the economic policy of the Russian Federation which lacks badly corresponding conditions has turned out to be insolvent and groundless and has provoked opposition from the community. The creation of the institutional mechanism of realization of transactor units multi-vector economic interests with regard to gender peculiarities as well as regulation of the structural shifts of the population employment will allow us to reduce transactional expenses realize in full volume the demographic potential and everything above will be conducive to the attraction of investors as well as the full-volume usage of the economic growth resources. 


\section{References}

Barron R., Norris G.M. Sexual divisions and the dual labour market. In D.L.Barket \& S.Allen (Eds.), Dependence and exploitation in work and marriage. New York, Longman, 1976.

Fakhrutdinova, E., Kolesnikova, J., Yurieva, O., Kamasheva, A. The commercialization of intangible assets in the information society/l World Applied Sciences Journal. Volume 27, Issue 13, 2013, Pages 82-86.

Becker G.S. A Treatise on the family. Cambridge; London: Harvard University Press, 1991, ch. 4, p/108-134.

Bergmann B. The Economic Emergence of Women. New York: Basic Books, 1986.

Gainova R.A., Shaidullin R.N., Safiullin L.N. and Maratkanova E.M. Infrastructural Component in Maintenance of Competitiveness of Region// World Applied Sciences Journal, 27(13), 2013, pp. 97-101.

Bagautdinova N.G., Safiullin L.N., Minnahmetov R.R. Institutionalization of Firm Environment in Conditions of Growing Turbulence/l Mediterranean Journal of Social Sciences.- Vol.5, No12, (2014)-pp.55-58.

Bragstand T. On the Significanse of Standarts for the Division of Work in the Household. Mimeo. University of Oslo, 1989.

Bagautdinova N.G., Kumpilova A.R., Boganchikova I.O., Shakhnina I.Z. Peculiarities of Public Administration of Development of Small Business in Modern Conditions// Mediterranean Journal of Social Sciences.- Vol.5, No12, (2014)-pp.87-92.

Bagautdinova N.G., Galieva G.T., Pakhmutov Ya.O., Pratchenko O.V. Methods of Regulation of Processes of Innovation Business Development// Mediterranean Journal of Social Sciences.- Vol.5, No12, (2014)-pp.75-80.

Ismagilova G.N., Safiullin L.N., Bagautdinova N.G. Tourism development in region based on historical heritage. Life Science Journal 2014; 11(6s):363-367.

Goldschmidt-Clermont L. Unpaid Work in the Household: A Review of Economic Evaluation Methods. Geneva: International Labour Offise, 1982.

Bagautdinova N.G., Safiullin L.N., Mubarakov I.A. The Role of Quality of Goods in Formation of Consumer Choice// Mediterranean Journal of Social Sciences.- Vol.5, No12, (2014)-pp.63-68.

Hartmann $\mathrm{H}$. The family as a locus of gender, class and political struggle: The example of housework. Sings, 1981.

Ulesov D.V., Shigabieva A.M., Maratkanova E.M. and Shaidullin R.N. Information Infrastructure of Small Business Development// World Applied Sciences Journal, 27(13), 2013, pp. 193-196.

Schultz T.W. (ed.). Economics of the Family. Chicago; London: University of Chicago Press, 1974.

Safiullin L.N., Fatkhiev A.M., Safiullina L.M. Projected trends and problems of education. Life Science Journal 2014; 11 (6s): $384-387$.

Wooley F.R. Welfare Economics and Its Critics: A Feminist Reappraisal. Mimeo. Carleton University, 1992.

Safiullin M.R., Samigullin I.G. and Safiullin L.N. Model of Management of Competitiveness of a Machine-building Complex// World Applied Sciences Journal, 27(13), 2013, pp. 212-216. 
